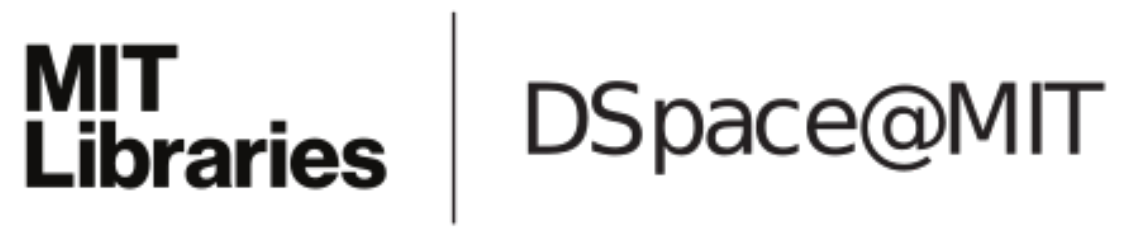

\author{
MIT Open Access Articles
}

Constraints on the Metabolic Activity of Microorganisms in Atacama Surface Soils Inferred from Refractory Biomarkers: Implications for Martian Habitability and Biomarker Detection

The MIT Faculty has made this article openly available. Please share how this access benefits you. Your story matters.

Citation: Wilhelm, Mary Beth et al. "Constraints on the Metabolic Activity of Microorganisms in Atacama Surface Soils Inferred from Refractory Biomarkers: Implications for Martian Habitability and Biomarker Detection." Astrobiology 18, 7 (July 2018): 955-966 ( 2018 Mary Ann Liebert, Inc.

As Published: http://dx.doi.org/10.1089/ast.2017.1705

Publisher: Mary Ann Liebert Inc

Persistent URL: https://hdl.handle.net/1721.1/129766

Version: Final published version: final published article, as it appeared in a journal, conference proceedings, or other formally published context

Terms of Use: Article is made available in accordance with the publisher's policy and may be subject to US copyright law. Please refer to the publisher's site for terms of use. 


\title{
Constraints on the Metabolic Activity of Microorganisms in Atacama Surface Soils Inferred from Refractory Biomarkers: Implications for Martian Habitability and Biomarker Detection
}

\author{
Mary Beth Wilhelm,,2 Alfonso F. Davila, Mary N. Parenteau, Linda L. Jahnke, Mastewal Abate, \\ George Cooper, Erin Taylor Kelly, Victor Parro García, Miriam G. Villadangos, \\ Yolanda Blanco, Brian Glass, James J. Wray, Jennifer L. Eigenbrode, \\ Roger E. Summons, and Kimberly Warren-Rhodes ${ }^{3}$
}

\begin{abstract}
Dryness is one of the main environmental challenges to microbial survival. Understanding the threshold of microbial tolerance to extreme dryness is relevant to better constrain the environmental limits of life on Earth and critically evaluate long-term habitability models of Mars. Biomolecular proxies for microbial adaptation and growth were measured in Mars-like hyperarid surface soils in the Atacama Desert that experience only a few millimeters of precipitation per decade, and in biologically active soils a few hundred kilometers away that experience two- to fivefold more precipitation. Diversity and abundance of lipids and other biomolecules decreased with increasing dryness. Cyclopropane fatty acids (CFAs), which are indicative of adaptive response to environmental stress and growth in bacteria, were only detected in the wetter surface soils. The ratio of trans to cis isomers of an unsaturated fatty acid, another bacterial stress indicator, decreased with increasingly dry conditions. Aspartic acid racemization ratios increased from 0.01 in the wetter soils to 0.1 in the driest soils, which is indicative of racemization rates comparable to de novo biosynthesis over long timescales ( $\sim 10,000$ years). The content and integrity of stress proteins profiled by immunoassays were additional indicators that biomass in the driest soils is not recycled at significant levels. Together, our results point to minimal or no in situ microbial growth in the driest surface soils of the Atacama, and any metabolic activity is likely to be basal for cellular repair and maintenance only. Our data add to a growing body of evidence that the driest Atacama surface soils represent a threshold for long-term habitability (i.e., growth and reproduction). These results place constraints on the potential for extant life on the surface of Mars, which is 100-1000 times drier than the driest regions in the Atacama. Key Words: Atacama Desert—DrynessGrowth-Habitability—Biomarker-Mars. Astrobiology 18, 955-966.
\end{abstract}

\section{Introduction}

M ARS HAS BEEN an extreme desert for most of its geologic history (e.g., Carr and Head, 2010). Therefore, a better understanding of the environmental limits of microbial tolerance to extreme dryness is relevant to long-term habitability models of Mars (Davila and Schulze-Makuch, 2016) and the search for evidence of life on the planet. This issue is particularly relevant after recent reports of possible transient liquid water activity on the surface of Mars (Martín-Torres et al., 2015; Ojha et al., 2015).

Surface soils in the driest region in the Atacama Desert in northern Chile are some of the most Mars like on Earth (Navarro-González et al., 2003). Desiccation and chemical

\footnotetext{
${ }^{1}$ School of Earth and Atmospheric Sciences, Georgia Institute of Technology, Atlanta, Georgia.

${ }^{2}$ Space Science and Astrobiology Division, NASA Ames Research Center, Moffett Field, California.

${ }^{3}$ Carl Sagan Center, SETI Institute, Mountain View, California.

${ }^{4}$ Departamento Evolución Molecular, Centro de Astrobiologia (INTA-CSIC), Madrid, Spain.

${ }^{5}$ Intelligent Systems Division, NASA Ames Research Center, Moffett Field, California.

${ }^{6}$ Planetary Environments Laboratory, NASA Goddard Space Flight Center, Greenbelt, Maryland.

${ }^{7}$ Department of Earth, Atmospheric, and Planetary Sciences, Massachusetts Institute of Technology, Cambridge, Massachusetts.
} 
stress in these hyperarid soils have resulted in some of the lowest levels of biomass observed in any terrestrial surface environment (Navarro-González et al., 2003; Ewing et al., 2008; Crits-Christoph et al., 2013). The metabolic potential of these surface soils provides a reference point with which to assess the potential for metabolic activity in soils on Mars.

Past investigations in the Atacama have largely focused on determining whether extant microorganisms are present in hyperarid soils, with variable success (Navarro-González et al., 2003; Connon et al., 2007; Lester et al., 2007; CritsChristoph et al., 2013; Azua-Bustos et al., 2015). Early studies in the hyperarid Yungay region failed to detect DNA or culturable microorganisms from the driest soils (NavarroGonzález et al., 2003), but follow-up studies demonstrated that viable microorganisms are in fact present (Connon et al., 2007; Lester et al., 2007; Crits-Christoph et al., 2013; Azua-Bustos et al., 2015). The question that has not yet been addressed is whether soil microorganisms are still capable of in situ growth and adaptation.

In the Atacama, the presence of viable cells or DNA is not necessarily evidence of biological activity or growth, because microorganisms could have been transported from other regions remaining in a state of stasis (Lester et al., 2007) or preserved from an early, wetter epoch in Atacama's history (Wilhelm et al., 2017). Laboratory incubation experiments, similar to those performed by the Viking Landers on Mars, showed no biological response in surface soils from the Yungay area, even after incubation for several days (Navarro-González et al., 2003). More recent laboratory incubations showed low levels of acetate mineralization in soils from the same area, but only after 7 days of incu- bation (Crits-Christoph et al., 2013), suggesting that actual growth would require rainfall levels significantly higher than the historical average (Davis et al., 2010). In situ proxies of short-term metabolic activity (i.e., hours to days) such as adenosine triphosphate (ATP) and RNA assays have been difficult to implement in this region because periods of active metabolism, such as rain events, are expected to be stochastic and short, often interspaced by 10 years or more (McKay et al., 2003). These proxies are also not necessarily indicative of adaptation and growth, since they could also reflect basal metabolism for cell maintenance and repair.

Instead, we followed an alternative strategy by conducting a survey of biomolecular proxies indicative of cell adaptation and growth that would record metabolic activity over long timescales (i.e., decades to millennia). Our hypothesis was that if desiccation-tolerant strains in the surface soils were capable of in situ adaptation and/or growth, this would be reflected in the composition of their cell membranes (lipid markers of stress) and in their protein makeup (stress proteins and amino acid racemization ratios). Because these biomolecular proxies are more recalcitrant in the environment than ATP or RNA, for example, particularly under the extreme dryness of the Atacama (Wilhelm et al., 2017), they serve as long-term indicators of metabolic processes.

We compared the relative abundance and integrity of these biomolecular proxies in surface soils from three of the driest locations in the Atacama $(<<2 \mathrm{~mm}$ precipitation/year) with locations c.a. $300 \mathrm{~km}$ to the south (approximately $5-10 \mathrm{~mm}$ precipitation/year) with sparse vegetation and hypolithic colonization, which represented biological positive controls (Fig. 1). We focused on surface soils only $(0-5 \mathrm{~cm})$, because

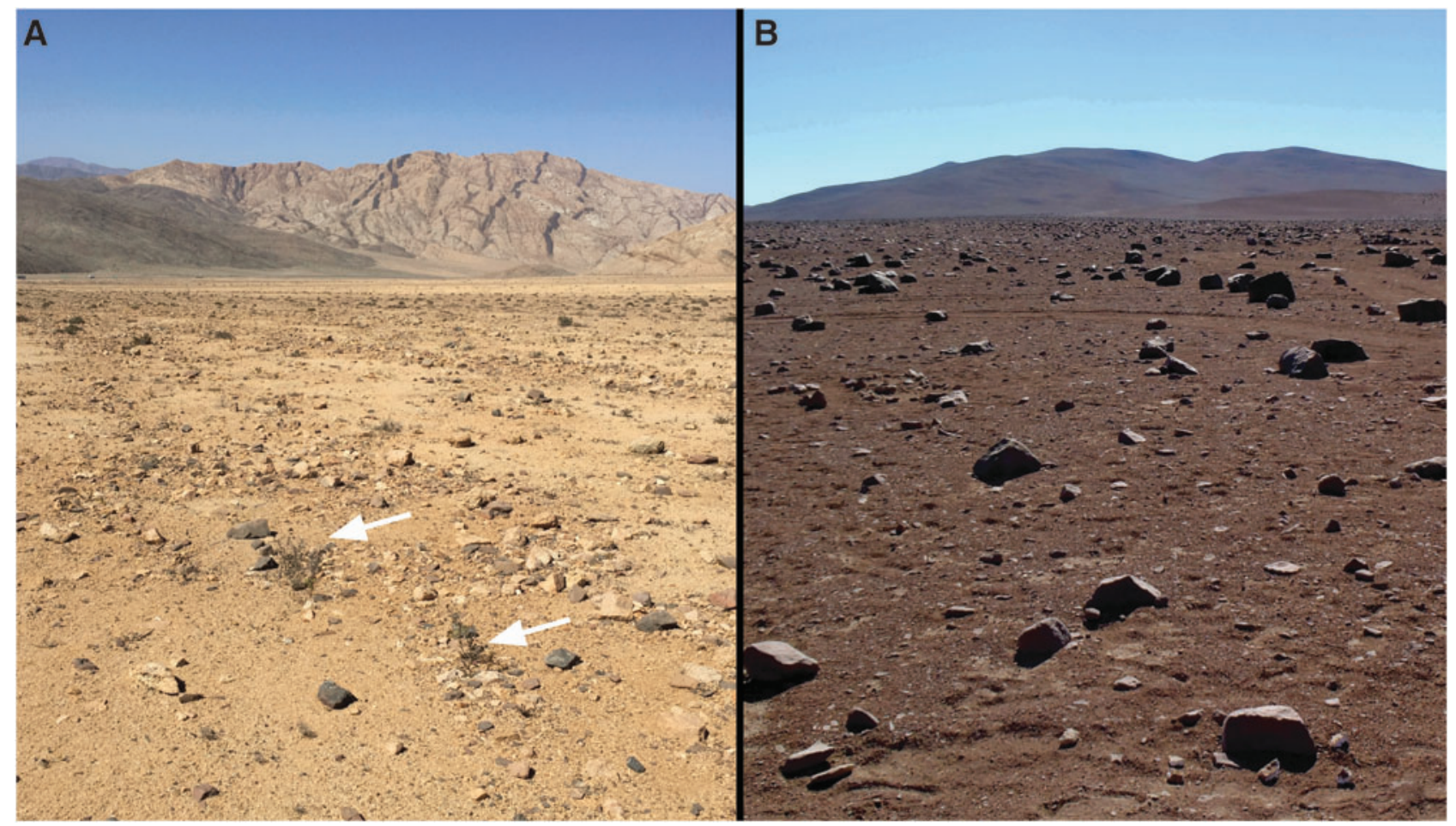

FIG. 1. Images of sampling locations in the Atacama Desert. (A) The "biological control" site for our study, Chañaral, that receives $\sim 10 \mathrm{~mm}$ of precipitation annually. Plants (white arrows), $<10 \%$ hypolithic colonization of stones, and lichens are present at this location. (B) One of the three hyperarid locations from our study, Yungay, receives $<<2$ mm of precipitation annually. Plants and lichens are absent from this region, and $<0.1 \%$ of stones show hypolithic colonization (Warren-Rhodes $e t$ al., 2006). 
these are the most Mars-like in terms of dryness, oxidants, and ultraviolet (UV) radiation (McKay et al., 2003; NavarroGonzález et al., 2003; Cockell et al., 2008). Lipid markers of stress and stress proteins were detected in samples from the biological control sites, but lipid markers of stress were absent in the three driest locations and stress proteins were present at much lower abundance, some with apparent compromised structural integrity. Our results suggest that microorganisms in the driest surface soils in the Atacama Desert are not capable of growth and adaptation, even over long periods of time, and that any spurts of metabolic activity during sporadic rain events are likely only sufficient for cell maintenance and repair.

\section{Methods}

\subsection{Field site description}

Mean annual precipitation at selected sample sites decreases from about 10 to $<<2 \mathrm{~mm} /$ year (Navarro-González et al., 2003). While the totality of our sample sites is considered hyperarid based on the United Nations Environmental Program (UNEP) Aridity Index (AI) definition ( $\mathrm{AI}<0.05$ ), AI values decline by an order of magnitude from 0.01 to 0.001 over the latitudes studied (Davila and Schulze-Makuch, 2016). Samples were collected from similar geological terrains that were locally identifiable alluvial fan surfaces (minimum exposure ages in excess of $2 \mathrm{My}$ ), and had been previously sampled and studied for their microbiology and soil proprieties (Fig. 2) (e.g., Ewing et al., 2006; Warren-Rhodes et al., 2006; Crits-Christoph et al., 2013). From south to north these sites included our positive "biological control" sites, Chañaral $\left(26^{\circ} 9^{\prime} 50.34^{\prime \prime} \mathrm{S}, 70^{\circ} 17^{\prime} 6.30^{\prime \prime} \mathrm{W}\right)$ and Altamira $\left(25^{\circ} 41^{\prime} 6.84^{\prime \prime} \mathrm{S}, 70^{\circ} 16^{\prime} 30.96^{\prime \prime} \mathrm{W}\right)$, intermediate site Aguas Calientes $\left(25^{\circ} 14^{\prime} 38.50^{\prime \prime} \mathrm{S}, 69^{\circ} 51^{\prime} 42.40^{\prime \prime} \mathrm{W}\right)$, and extreme hyperarid sites Mina Julia (24 $\left.53^{\prime} 37.74^{\prime \prime} \mathrm{S}, 69^{\circ} 53^{\prime} 55.38^{\prime \prime} \mathrm{W}\right)$, Yungay $\left(24^{\circ} 6^{\prime} 5.16^{\prime \prime} \mathrm{S}, 70^{\circ} 1^{\prime} 5.04^{\prime \prime} \mathrm{W}\right)$, and Maria Elena $\left(22^{\circ} 16^{\prime} 5.82^{\prime \prime} \mathrm{S}, 69^{\circ} 43^{\prime} 18.48^{\prime \prime} \mathrm{W}\right)$.

Only surface soils $(0-5 \mathrm{~cm})$ from each site were analyzed because they are the most Mars like. Surface soils dry the fastest after a rain event (Davis et al., 2010) and thus present the greatest desiccation challenge. In addition, microorganisms in these surface soils must face high levels of radiation (Cockell et al., 2008), large temperature fluctuations (McKay et al., 2003), and the chemical attack of soil and atmospheric oxidants (Georgiou et al., 2015). The water activity in surface soils in this hyperarid region is well below the threshold for microbial growth during an average diurnal cycle (Connon et al., 2007).

Rubrobacterales, Actinomycetales, Acidimicrobiales, a number of families from the Thermoleophilia, and an extremely low abundance of Firmicutes were previously reported in surface soils from Chañaral to Yungay, with the lowest levels of diversity observed in the driest hyperarid soils (Crits-Christoph et al., 2013). In addition, the hyperarid region of the Atacama is characterized by a general lack of habitation by plants, lichens, archaea, and hypolithic communities (Navarro-González et al., 2003; Warren-Rhodes et al., 2006), with cell counts estimated to be between 10 and 10,000 cells per gram of soil (NavarroGonzález et al., 2003; Crits-Christoph et al., 2013).

\subsection{Sample collection}

Samples were collected for laboratory analyses in September 2014. In addition, immunoassays (see section 2.6)

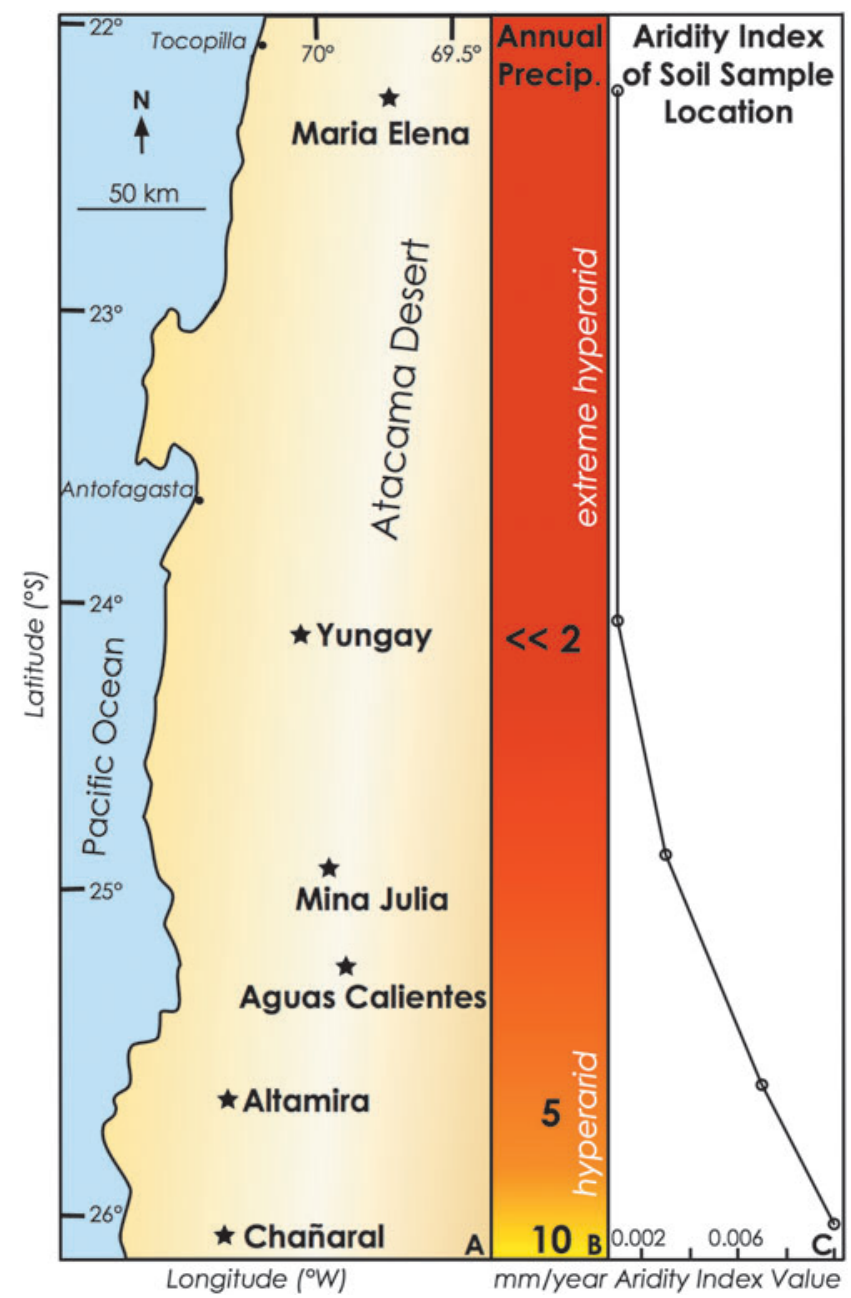

FIG. 2. Map and aridity at study locations. (A) Map of the region of interest in the Atacama Desert with sites of soil locations analyzed marked with stars. Sites were chosen along a previously studied north to south aridity gradient (NavarroGonzález et al., 2003; Warren-Rhodes et al., 2006; Ewing et al., 2008; Crits-Christoph et al., 2013). (B) Annual precipitation measurements in millimeters are written at approximate latitudinal locations. Red color indicates "extreme hyperarid" region experiencing $<<2 \mathrm{~mm}$ precipitation per year, or decadal rain events (McKay et al., 2003). Orange and yellow colors indicate hyperarid regions that receive $5-10 \mathrm{~mm}$ of precipitation annually, respectively. Based on figures from NavarroGonzález et al. (2003) and Warren-Rhodes et al. (2006). (C) AI values for soil sites (taken from Davila and Schulze-Makuch, 2016). AI is defined as the ratio of mean annual precipitation to potential evapotranspiration. Based on the AI scale, hyperaridity is defined $\mathrm{AI}<0.05$. Based on this definition, the entire region of interest is considered hyperarid. Dryness increases along a south to north transect. AI, aridity index.

were performed on-site in the Atacama in February 2017 on samples collected at selected sites. Due to the extremely low inventory of biomass in Atacama soils (Ewing et al., 2006), samples were collected by scientists wearing full-body, sterile, clean-room suits $(<1$ colony forming unit per 10,000 garments), masks, glasses, and gloves to minimize the introduction of anthropogenic biological contaminants (Meadow et al., 2015) during sampling. 
Soil samples were excavated between 0 and $5 \mathrm{~cm}$ depth at each site over a surface area of $\sim 30$ by $30 \mathrm{~cm}$. A solventcleaned spoon was used to scoop samples into three $8 \mathrm{oz}$ glass jars (holding $\sim 300 \mathrm{~g}$ of soil each) that had been heated to $500^{\circ} \mathrm{C}$ for more than $8 \mathrm{~h}$ to combust all traces of organic material. Each sample was collected with a different spoon to minimize cross contamination. Samples were kept frozen during transport $(<16 \mathrm{~h})$ and then stored at $-20^{\circ} \mathrm{C}$ until analysis.

\subsection{Lipid extractions and analysis}

Glass jars containing samples were removed from the $-20^{\circ} \mathrm{C}$ freezer and kept for $30 \mathrm{~min}$ to $1 \mathrm{~h}$ at room temperature to prevent condensation of moisture onto the soil. Soils were not lyophilized to reduce the exposure time to the laboratory environment and minimize contamination risk; this step was not considered critical given the extremely low water content in the soils (Wilhelm et al., 2017). Preliminary samples that were lyophilized to estimate water content in soil showed only $1.4 \%$ reduction in mass due to water loss.

Hundreds of grams of soil were removed from the glass jars and then homogeneously powdered with a ceramic mortar and pestle that had been previously solvent rinsed and combusted $\left(550^{\circ} \mathrm{C}, 12 \mathrm{~h}\right)$. Soil mass was scaled based on previously measured lipid abundances in these soils (Wilhelm et al., 2017), to ensure detection of lipids of low relative abundance such as $\mathrm{C}_{17}$ cyclopropane fatty acids (CFAs; $88.8 \mathrm{~g}$ of Chañaral soil to $221.7 \mathrm{~g}$ of biomass-lean Yungay soil).

Soil samples were extracted by using a modified Bligh and Dyer (1959) protocol (Jahnke et al., 1992). The protocol was modified primarily to minimize transfer steps and contamination and loss of biomass during extraction (Wilhelm et al., 2017). Three extractions were performed on powdered sample: $40 \mathrm{~mL}$ of high-performance liquid chromatography (HPLC)-grade water, $100 \mathrm{~mL}$ of pesticide-grade methanol, and $50 \mathrm{~mL}$ of pesticide grade-methylene chloride (DCM). After the addition of solvents, the resultant slurry was sonicated, stirred, and left to settle until solvent became mostly clear, at which point it was poured into a new previously combusted flask.

Solvent extracts were then added to a solvent-washed Teflon separatory funnel with $180 \mathrm{~mL}$ of extract and $47 \mathrm{~mL}$ of DCM and inverted two times to mix. Water $(47 \mathrm{~mL})$ was then added to drive the methanol into the aqueous phase, and the mixture was gravimetrically separated. The DCM layer was slowly drained into a new flask; the methanol and water phase discarded. The resulting extract was evaporated under a stream of $\mathrm{N}_{2}$ and transferred into smaller previously combusted vials until $\sim 100 \mu \mathrm{L}$ remained. Care was taken to minimize the number of containers used in the evaporation process and to thoroughly rinse and sonicate the sides of all vessels after draining to recover any lipid left behind. This evaporation process concentrated the extract by roughly three orders of magnitude.

Thirty percent of the total lipid extract (TLE) was used for analysis by gas chromatography/mass spectrometry (GCMS). The TLE was derivatized via a medium acid hydrolysis using commercial methanolic $\mathrm{HCl} 0.5 \mathrm{~N}$ (LC08137B; Supelco) following the Kates (1986) procedure, which adds a methyl group to the carboxyl moiety of any free fatty acids present (Wilhelm et al., 2017), and also transesterifies complex lipids (membrane-bound fatty acids, such as phospholipids and glycolipids) to generate fatty acid methyl esters (FAME). This acid methanolysis treatment generates a "total" solvent-extractable fatty acid pool present as FAME. An unsaturated $\mathrm{C}_{22: 1}$ FAME standard $(40 \mu \mathrm{L}$ of a $25 \mathrm{ng} / \mu \mathrm{L}$ standard; Sigma-Aldrich) was then added to the TLE for a mass of $25 \mathrm{ng}$ per $1 \mu \mathrm{L}$ injection into the GC-MS.

The final volume of $30 \%$ of the derivatized TLE in DCM was $40 \mu \mathrm{L}$, which contained $30 \%$ of the derivatized TLE. One-fortieth of this volume was then injected into the GCMS. GC-MS of lipids was performed on an Agilent 7890B GC-5977A MSD system equipped with an Agilent DB-5MS column $(60 \mathrm{~m} \times 250 \mu \mathrm{m} \times 0.25 \mu \mathrm{m}$; Agilent $)$ with high-purity helium as carrier gas at $1 \mathrm{~mL} / \mathrm{min}$. The inlet temperature was $280^{\circ} \mathrm{C}$. Initial oven temperature was $50^{\circ} \mathrm{C}$, ramped to $120^{\circ} \mathrm{C}$ at $10^{\circ} \mathrm{C} / \mathrm{min}$, then increased from $120^{\circ} \mathrm{C}$ to $320^{\circ} \mathrm{C}$ at $4^{\circ} \mathrm{C} /$ $\mathrm{min}$, and held at this temperature for $5 \mathrm{~min}$. The MS source temperature was $280^{\circ} \mathrm{C}$. Our instrument is capable of detecting $1 \mathrm{pg}$ of a $\mathrm{C}_{23}$ FAME standard using the same $60 \mathrm{~m}$ DB-5MS column and heating protocol used in analysis.

\subsection{Monounsaturated fatty acid double-bond position and cyclopropane fatty acid determination}

Because it is difficult to distinguish unsaturated fatty acids from CFAs due to similar elution and mass spectral patterns, the unsaturated fatty acids were derivatized by using dimethyl disulfide (DMDS) to determine the double-bond positions (Yamamoto et al., 1991), as well as chromatographically separate these compounds from the CFA. The FAME fraction (30\% of the TLE) was added to a reaction vial, treated with $300 \mu \mathrm{L}$ DMDS and $4 \mathrm{mg}$ iodine, and heated to $35^{\circ} \mathrm{C}$ for $30 \mathrm{~min}$ and cooled. One milliliter of hexane-diethyl ether (1:1) was added to this mixture and then it was titrated with $10 \%$ aqueous $\mathrm{Na}_{2} \mathrm{~S}_{2} \mathrm{O}_{3}$. The FAME-DMDS adducts, as well as unreacted saturated FAME and CFA, were extracted with hexane:dichloromethane $(4: 1, \mathrm{v}: \mathrm{v})$ and concentrated to a final volume of $20 \mu \mathrm{L}$. One of twenty microliters of this final volume was injected on the GC-MS using the previously described chromatographic conditions. Mono- and diunsaturated FAMEs form DMDS adducts with distinct spectra that elute at later points in the chromatogram, whereas CFAs are unaffected by this treatment and remain at the same elution time as in the previous FAME chromatogram. FAMEs are described using the nomenclature "number of carbons:number of unsaturations," followed by double-bond locations referenced from the delta $(\Delta)$, or carboxylic, end of the molecule.

\subsection{Bound amino acid extraction and analysis}

Only previously unopened jars of soil samples were used for amino acid analyses. All extraction steps were done in a Labconco B2 biosafety cabinet that intakes air and passes it through an High Efficiency Particular Arrestance (HEPA) filtration system, substantially lowering the risk of contaminating biomasspoor samples. The interior filtered environment of this biosafety cabinet is certified as a Class 100 clean room. Scientists wore clean-room suit sleeves while working with the samples inside the biosafety cabinet to further reduce the risk of anthropogenic contamination of samples. Samples were first ground in a unique mortar and pestle that was previously heated to $550^{\circ} \mathrm{C}$ for $12 \mathrm{~h}$. 
An acid hydrolysis extraction protocol was utilized to liberate bound amino acids (i.e., proteins, humic complexes, peptides) from soils. It is estimated that in typical soils, $99.5 \%$ of amino acids are in a bound (polymeric) form and the remainder are "free" (Stevenson, 1982). These proportions, estimations of the concentration of amino acids relative to other biomarker classes already measured in Yungay soils (Wilhelm et al., 2017), and instrument detection limits were taken into account to determine the approximate mass of soil required for extraction. A total of $2.5 \mathrm{~mL}$ of $6 \mathrm{M} \mathrm{HCl}$ in amino acid-free $\mathrm{H}_{2} \mathrm{O}$ (Sigma-Aldrich) was added to $\sim 3 \mathrm{~g}$ of ground soil in heat-cleaned $\left(550^{\circ} \mathrm{C}\right.$ for $\left.12 \mathrm{~h}\right)$ glass reaction vials. Vials were then sealed and heated for $24 \mathrm{~h}$ at $100^{\circ} \mathrm{C}$ (Bada et al., 1999), filtered through combusted silica filters to remove solid particles, and dried on a rotary evaporator.

In preparation for chiral analysis by GC-MS, each sample was acidified and desalted with a column of ion exchanging resin: AG 50W-X4, 100-200. After drying, the carboxyl and amine moieties on the amino acids were derivatized with a mixture of (+)-2-butanol/acetyl chloride to form (+)butyl esters (on carboxyl groups) and a mixture of trifluoroacetic anhydride (TFAA)/ethyl acetate to add trifluoroacetyl groups to amino nitrogens, the resulting compounds are " $(+)$ butyl/ TFA" derivatives. After complete drying, each sample was brought to a final volume of $40 \mu \mathrm{L}$ with ethyl acetate; this represented $30 \%$ of the derivatized amino-acid extract. One microliter of each was injected into a GC-MS. This GC-MS was an Agilent 6890N GC coupled to a 5975 MS (Agilent). The GC oven was equipped with an Agilent DB-17MS column $(60 \mathrm{~m} \times 0.250 \mathrm{~mm} \times 0.25 \mu \mathrm{m}$, with helium as carrier gas at $1 \mathrm{~mL} / \mathrm{min})$. The inlet temperature was $230^{\circ} \mathrm{C}$; initial oven temperature was $35^{\circ} \mathrm{C}$; oven was ramped to $70^{\circ} \mathrm{C}$ at $3^{\circ} \mathrm{C} / \mathrm{min}$ and held $30 \mathrm{~min}$, temperature then increased to $90^{\circ} \mathrm{C}$ at $2^{\circ} \mathrm{C} / \mathrm{min}$, then increased to $230^{\circ} \mathrm{C}$ at $3^{\circ} \mathrm{C} / \mathrm{min}$, and held for $60 \mathrm{~min}$; MS source temperature was $280^{\circ} \mathrm{C}$. In this configuration, the GC-MS is capable of detecting low femtomole quantities of amino acids. Laboratory blanks were found to be free of amino acids.

\subsection{Immunoassay antibody microarrays: printing life detector chip and fluorescent sandwich immunoassay}

The life detector chip (LDChip) is an antibody microarraybased biosensor (Rivas et al., 2008; Parro et al., 2011, 2016) that contains more than 200 antibodies with broad specificities produced against biological polymers, including lipo/exo-polysaccharides; bacterial strains belonging to main taxonomic groups (alpha-, beta-, gamma-, deltaProteobacteria; Cyanobacteria, Actinobacteria, Firmicutes, Bacteroidetes); and archaea, among others (Rivas et al., 2008; Parro et al., 2011, 2016). We used the LDChip to analyze samples from the biological control sites, as well as Yungay, Mina Julia, and Aguas Calientes. Samples were analyzed in the field a few hours after collection.

The immunoglobulin (IgG) fraction of each antibody (after protein A affinity purification) was printed on epoxyactivated glass slides (Arrayit) using a MicroGrid II TAS arrayer (Biorobotics, Genomic Solutions) as reported previously (Rivas et al., 2008; Parro et al., 2011). For the fluorescent multiplex sandwich immunoassay, all protein A-purified antibodies were fluorescently labeled with Alexa 647 fluorochrome (Molecular Probes) following vendor recommendations, checked, titrated and used as described (Rivas et al., 2008; Blanco et al., 2017).

2.6.1. Sample preparation and immunoassays with LDChip. Up to $0.5 \mathrm{~g}$ of soil samples were suspended in $2 \mathrm{~mL}$ of TBSTRR buffer $(0.4 M$ Tris- $\mathrm{HCl} \mathrm{pH} 8,0.3 \mathrm{M} \mathrm{NaCl}$, $0.1 \%$ Tween 20) and sonicated using a manual and portable ultrasonicator (Dr. Hielscher $50 \mathrm{~W}$ DRH-UP50H sonicator; Hielscher Ultrasonics, Berlin, Germany) for $3 \times 1$-min cycles, with 30-s pauses on ice. Then, samples were filtered through $5 \mu \mathrm{m}$ nitrocellulose filters to remove sand and coarse material. The filtrates were used as a multianalytecontaining sample for the fluorescent sandwich microarray immunoassays (FSMI) as described in previous works (Parro et al., 2011, 2016; Blanco et al., 2017).

2.6.2. LDChip image processing and quantification. The LDChip microarray images were analyzed and quantified by GenePix Pro Software (Molecular Devices, Sunnyvale, CA). The local background (B) as quantified by GenePix software was subtracted. Then, the final fluorescence intensity A of each antibody spot was calculated following the equation: $\mathrm{A}=(\mathrm{F} 635-\mathrm{B})$ sample $-(\mathrm{F} 635-\mathrm{B})$ blank, where F635 is the median of the fluorescence of all the spot pixels at $635 \mathrm{~nm}$, either from the sample or the blank assay (only buffer instead of sample), as previously reported (Rivas et al., 2008; Parro et al., 2011). An additional 2.5 times the average of A was applied as cutoff value to all spots of the array to minimize false positives.

\section{Results}

\subsection{Lipids and amino acids}

The abundance and diversity of free and membranebound fatty acids analyzed as FAME generally decreased with decreasing AI values (Figs. 3 and 4). The number of unique fatty acids detected decreased from 138 in the Chañaral surface soils to $<50$ in Yungay and Maria Elena soils (Fig. 4). These FAMEs included chain lengths between $\mathrm{C}_{12}$ and $\mathrm{C}_{30}$ and the alkyl chains included terminal and midchain methyl branches, mono- and polyunsaturated bonds, and, sometimes, a second carboxyl function. The lowest total abundance of normal, straight-chain saturated fatty acids (SFAs) measured was in Yungay and Maria Elena soils (Fig. 3). Yungay soils had $0.089 \mu \mathrm{g}$ of $n-\mathrm{C}_{12: 0}$ to $n-\mathrm{C}_{30: 0}$ SFAs per gram of soil. Chañaral and Altamira soils contained 0.4 and $1.5 \mu \mathrm{g} / \mathrm{g}$ soil, respectively (4.6-17.2 times more normal that SFAs than Yungay soils).

The $\mathrm{C}_{17}$ CFAs were only detected in Chañaral and Altamira soils at abundances of 0.05 and $0.12 \mu \mathrm{g} / \mathrm{g}$ soil, respectively (Fig. 5), with a ratio of CFAs to SFAs of 0.12 in Chañaral and 0.07 in Altamira. CFAs were not detected in Mina Julia, Yungay, and Maria Elena soils. Assuming a similar ratio of CFAs to SFAs $(\sim 0.1)$ at the driest sites, the expected abundance of CFA in Yungay would still have been well above the detection limit of the instrument $\left(<1 \mathrm{pg} \mathrm{C}_{17} \mathrm{CFA}\right.$ per gram of soil), especially given the increased mass of soil extracted from the drier surface soils analyzed. Therefore, the absence of CFA in Yungay cannot be readily attributed to signal dilution due to lower biomass.

Yungay soils contained the fewest distinct monounsaturated fatty acids, with only two detected in soils collected at 


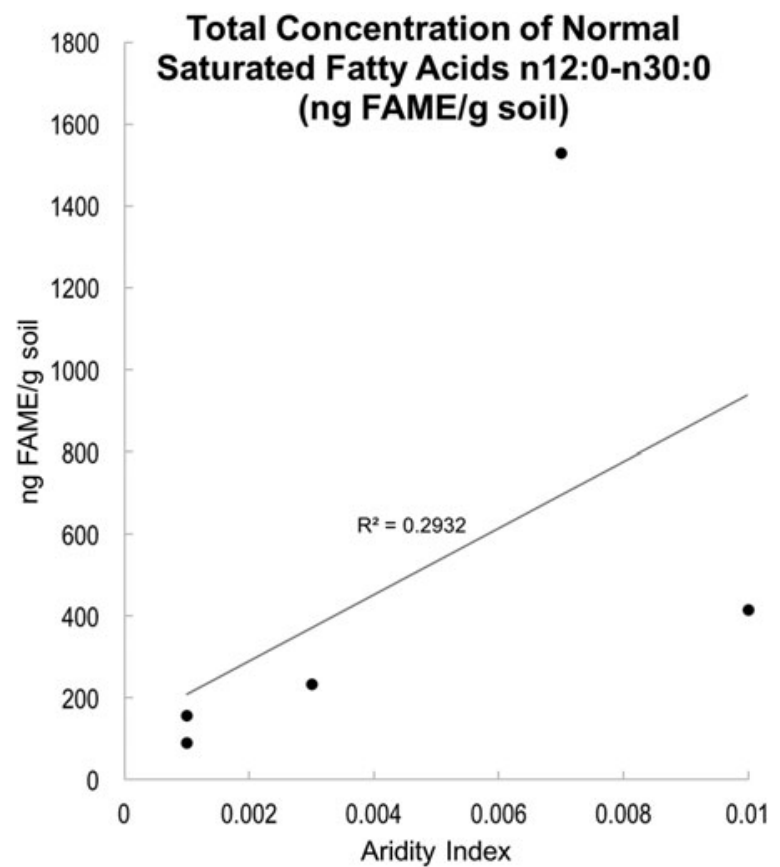

FIG. 3. Total concentration of normal fatty acids in Atacama soils with increasing dryness. The total concentration of normal, saturated fatty acid methyl esters $n-\mathrm{C}_{12: 0}$ to $n$ $\mathrm{C}_{30: 0}$ contained in soils in nanograms of FAME per gram of soil. Values indicate the total amount of common membrane lipids of living, dormant, and possibly dead organisms (Wilhelm et al., 2017). FAME, fatty acid methyl ester.

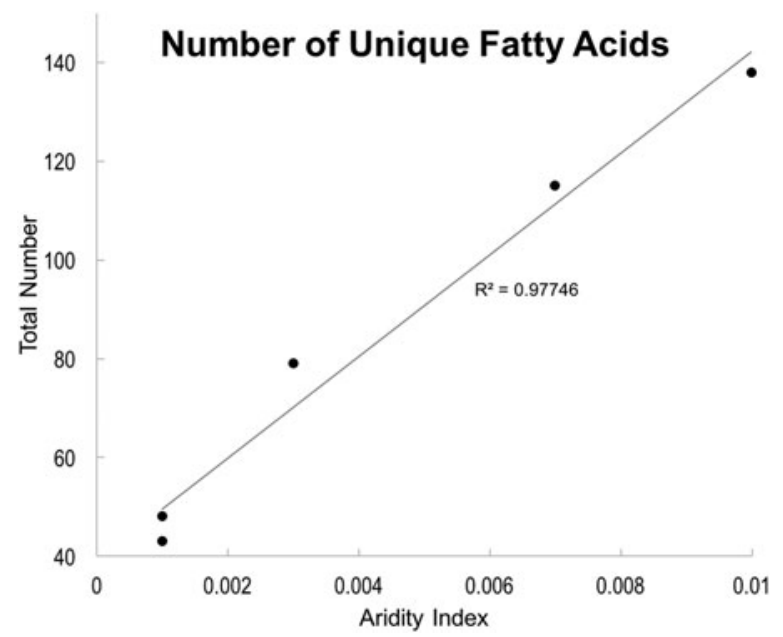

FIG. 4. Total number of unique fatty acids in Atacama soils with increasing dryness. A positive linear correlation is found between the total number of unique fatty acids and AI. The number of unique fatty acids in soils decreases approximately three times with an order of magnitude decline in AI value. Fatty acids containing 12-30 carbons, including normal and saturated, dicarboxylic, branched, multibranched, and mono and polyunsaturated fatty acids, are included in this total number, and can be used as a proxy for diversity of organisms contained within the soil.

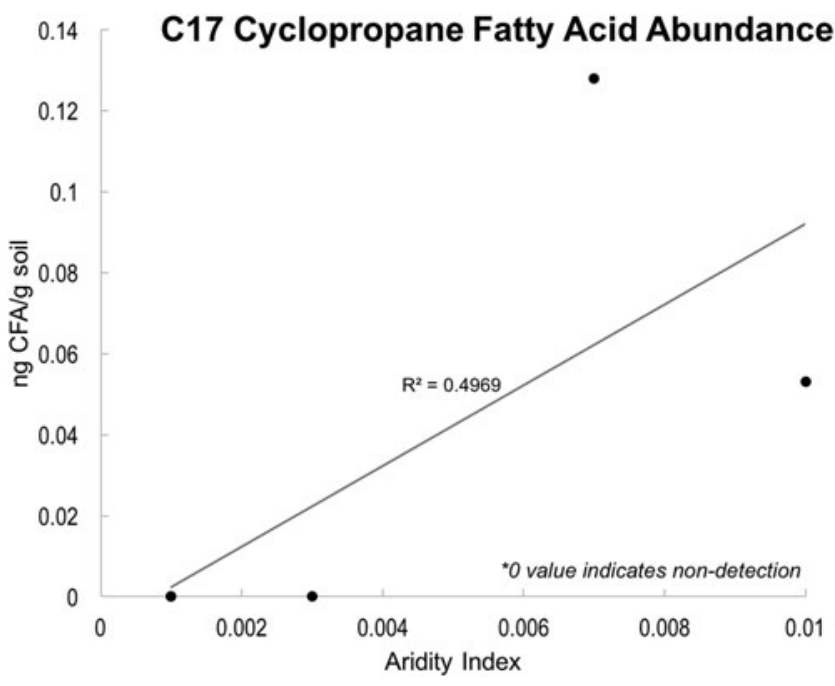

FIG. 5. Cyclopropane fatty acid abundance in Atacama soils with increasing dryness. CFAs were only detected in Altamira and Chañaral soils. Values of 0 at the drier sites indicate that CFAs were not detected. The presence of these lipids typically indicates bacterial modulation of membrane conditions under stressful conditions and formed predominately during the stationary phase of growth. CFAs, cyclopropane fatty acids.

the "Yungay North" site. Altamira and Chañaral had much higher monounsaturated fatty acid content, exhibiting similar diversity to each other (Table 1). Only the $n-\mathrm{C}_{16: 1 \Delta 9}$ and $n-\mathrm{C}_{18: 1 \Delta 9}$ monounsaturated fatty acids were detected in all samples analyzed (Table 1). Both cis and trans 16:1 $\Delta 9$ were detected at all sites, and this unsaturated fatty acid was the only one to have detectable cis and trans isomers. All ratios of trans to cis $n-\mathrm{C}_{16: 1 \Delta 9}$ were $\leq 0.01$, but the ratio decreased with increasing dryness (Fig. 6). The highest trans/cis value measured was in Chañaral soils at 0.012, and the lowest value was 0.003 in Maria Elena soils.

The $\mathrm{D} / \mathrm{L}$ ratios of hydrolyzed aspartic acid increased fivefold with decreasing aridity (Fig. 7), indicating that greater racemization had occurred at drier sites. Specifically,

Table 1. Normal Monounsaturated Fatty Acid and Bond Position Detected in Atacama Aridity Transect Samples

\begin{tabular}{|c|c|c|c|c|c|c|}
\hline & Chañaral & Altamira & $\begin{array}{c}\text { Mina } \\
\text { Julia }\end{array}$ & $\begin{array}{c}\text { Yungay } \\
\text { North }\end{array}$ & $\begin{array}{l}\text { Yungay } \\
\text { South }\end{array}$ & $\begin{array}{l}\text { Maria } \\
\text { Elena }\end{array}$ \\
\hline$n-\mathrm{C}_{14: 1 \Delta 7}$ & $\mathrm{x}$ & & & & & \\
\hline$n-\mathrm{C}_{15: 1 \Delta 4}$ & & $\mathrm{x}$ & & & & \\
\hline$n-\mathrm{C}_{15: 1 \Delta 7}$ & $\mathrm{x}$ & $\mathrm{X}$ & & & $\mathrm{X}$ & $\mathrm{x}$ \\
\hline$n-\mathrm{C}_{15: 1 \Delta 9}$ & $\mathrm{x}$ & $\mathrm{x}$ & $\mathrm{x}$ & & $\mathrm{x}$ & $\mathrm{x}$ \\
\hline$n-\mathrm{C}_{15: 1 \Delta 9}$ & & & $\mathrm{x}$ & & & \\
\hline$n-\mathrm{C}_{16: 1 \Delta 9}$ & $\mathrm{x}$ & $\mathrm{x}$ & $\mathrm{x}$ & $\mathrm{x}$ & $\mathrm{x}$ & $\mathrm{x}$ \\
\hline$n-\mathrm{C}_{16: 1 \Delta 11}$ & $\mathrm{x}$ & $\mathrm{x}$ & $\mathrm{x}$ & & & \\
\hline$n-\mathrm{C}_{17: 1 \Delta 9}$ & $\mathrm{x}$ & $\mathrm{x}$ & $\mathrm{x}$ & & $\mathrm{x}$ & $\mathrm{x}$ \\
\hline$n-\mathrm{C}_{17: 1 \Delta 11}$ & $\mathrm{x}$ & $\mathrm{x}$ & $\mathrm{x}$ & & & $\mathrm{x}$ \\
\hline$n-\mathrm{C}_{18: 1 \Delta 9}$ & $\mathrm{x}$ & $\mathrm{x}$ & $\mathrm{x}$ & $\mathrm{x}$ & $\mathrm{x}$ & $\mathrm{X}$ \\
\hline$n-\mathrm{C}_{18: 1 \Delta 11}$ & $\mathrm{x}$ & $\mathrm{x}$ & $\mathrm{x}$ & & $\mathrm{x}$ & $\mathrm{x}$ \\
\hline$n-\mathrm{C}_{18: 1 \Delta 13}$ & $\mathrm{x}$ & & $\mathrm{x}$ & & & \\
\hline$n-\mathrm{C}_{19: 1 \Delta 9}$ & $\mathrm{x}$ & $\mathrm{x}$ & $\mathrm{x}$ & & & $\mathrm{x}$ \\
\hline$n-\mathrm{C}_{19: 1 \Delta 11}$ & & & $\mathrm{x}$ & & & \\
\hline$n-\mathrm{C}_{20: 1 \Delta 11}$ & $\mathrm{x}$ & $\mathrm{x}$ & $\mathrm{x}$ & & & \\
\hline$n-\mathrm{C}_{22: 1 \Delta 13}$ & & $\mathrm{x}$ & $\mathrm{x}$ & & & $\mathrm{x}$ \\
\hline
\end{tabular}




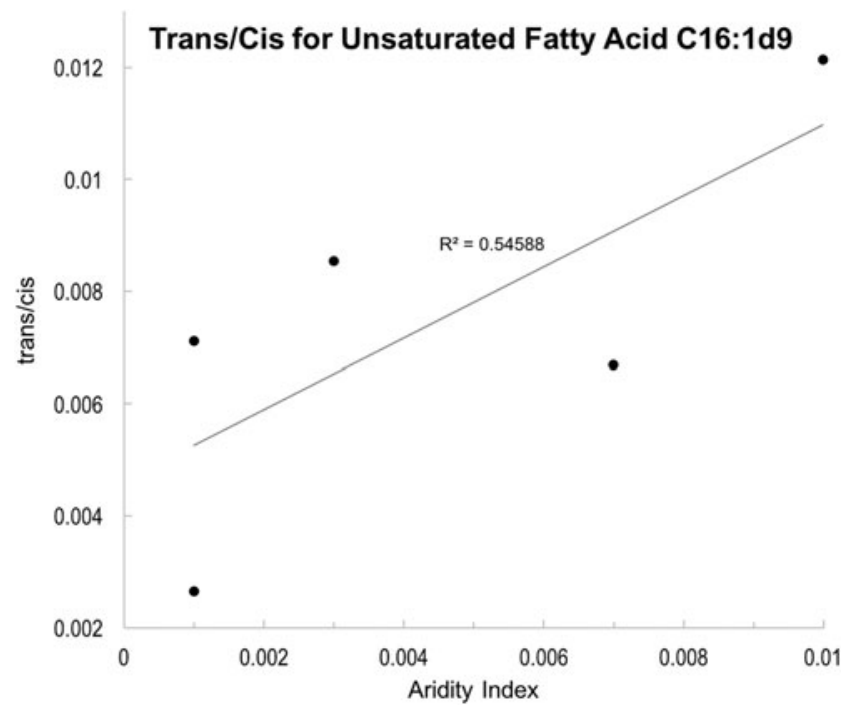

FIG. 6. Ratio of trans/cis confirmation of the double bond of unsaturated fatty acid $n-\mathrm{C}_{16: 1 \Delta 9}$ in Atacama soils with increasing dryness. The unsaturated fatty acid $n-\mathrm{C}_{16: 1 \Delta 9}$ was the only unsaturated fatty acid detected in all Atacama samples in which both cis and trans isomers of the double bond on $\mathrm{C}_{9}$ were present. The ratio of trans to cis for $n-\mathrm{C}_{16: 1 \Delta 9}$ was found to decrease with increasing dryness. Bacteria modulate membrane fluidity in response to environmental stressors by converting the cis isomer to trans. Although we might expect this ratio to decrease with increasing dryness, the opposite is observed, potentially indicating that microorganisms contained in the driest soils along the transect are not able to enter a growth phase and/or signal dilution via input of biomass from external sources is occurring.

Chañaral soils were found to have $\mathrm{D} / \mathrm{L}$ ratios of 0.02 , versus 0.10 in Yungay soils.

\subsection{LDChip immunoassay}

Total immunoassay fluorescence decreased from Chañaral to Yungay by a factor of 24 (Fig. 8). A large fraction $(>75 \%)$

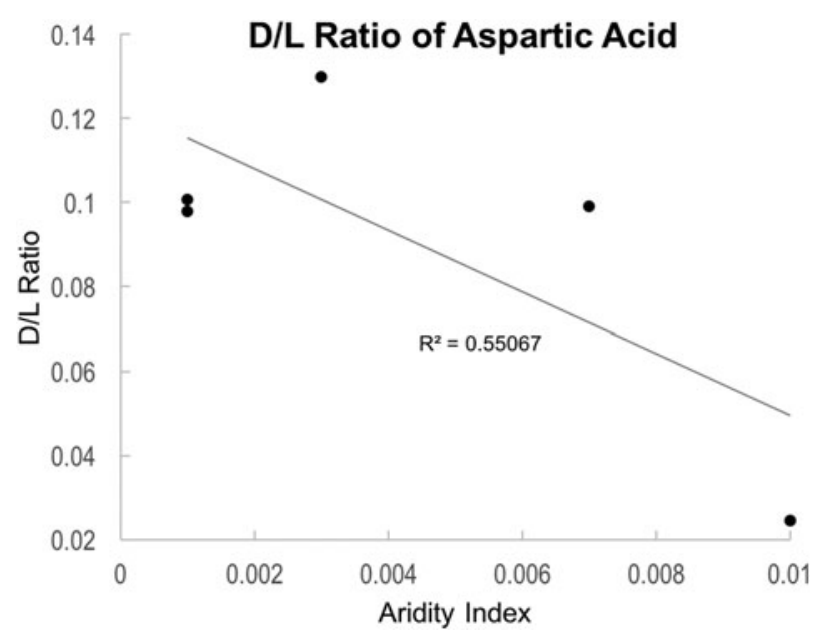

FIG. 7. D/L ratio of aspartic acid in Atacama soils with increasing dryness. D/L ratios of aspartic acid from hydrolyzed proteins, peptides, and humic complexes contained in soils are found to increase with increasing dryness. Increased racemization indicates that older organic material is contained in drier soils.

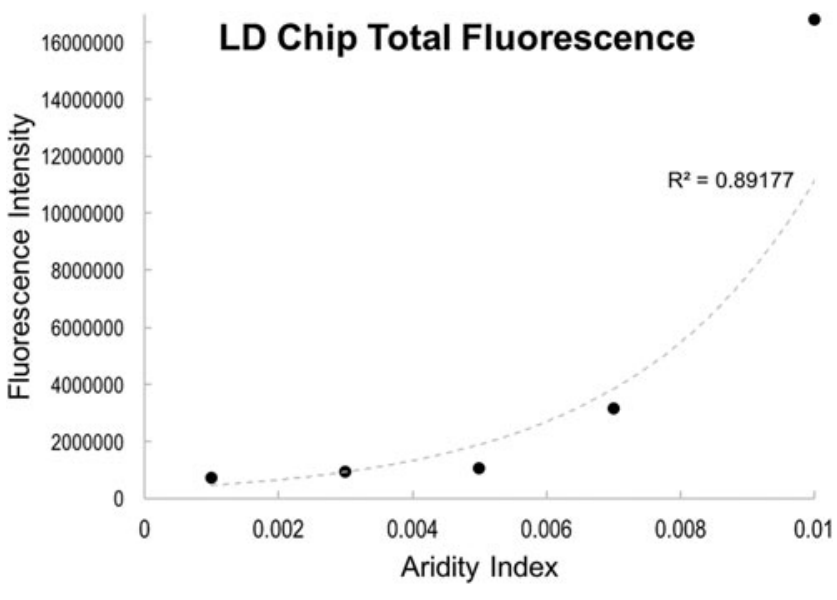

FIG. 8. LDChip total fluorescence in Atacama soils with increasing dryness. The total LDChip antibody microarray florescence, the sum of florescence of 242 spots ( 3 per assayed sample) after corrected by the background, and the blank chip. Fluorescence was found to significantly decrease with increasing dryness. The LDChip was designed to enable identification of the main phylogenetic groups of bacteria, many universal proteins and peptides used in different types of metabolisms. LDChip, life detector chip.

of the antibody spots showed positive fluorescence in Chanaral soils, indicating the presence of abundant polymeric biological material. By contrast, only $7 \%$ (18/242) were positive in Yungay, Mina Julia, and Aguas Calientes soils, mainly corresponding to antibodies, proteins, and peptides, and Cyanobacteria from the Synechocystis genus.

Seven peptides were detected of 73 tested in all surface soils analyzed (Fig. 5), including dehydrin (DhnA), water stress hypersensitive response (WshR), high-temperature (HtpG), poly(3-hydroxyalkanoate) polymerase subunit (PhaC), iron stress-induced chlorophyll-binding (IsiA), and superoxide dismutase (SodA and SodF). The immunoassay signal for these peptides decreased by up to an order of magnitude toward the driest sites. As the aridity decreased, the number of antibodies recognizing microbial markers increased, particularly those corresponding to Gram-positive bacteria (Firmicutes and Actinobacteria).

\section{Discussion}

Our study was designed to determine whether surface soils $(0-5 \mathrm{~cm})$ in the driest parts of the Atacama Desert can still support microbial growth and adaptation. The distinction is important because research in other extreme, oligotrophic environments has shown that metabolic processes can fall into three main groupings: (1) growth; (2) maintenance of functions without growth; and (3) survival, in which cells can repair macromolecular damage but are probably largely dormant (Morita, 1998; Price and Sowers, 2004). While the definition of habitability can imply an environment capable of supporting metabolic activity allowing for survival, maintenance, or growth (i.e., instantaneous habitability), growth and reproduction are required for the long-term persistence of a community (Cockell et al., 2016).

We focused on the surface soils because they are the most Mars like in terms of dryness, UV radiation, and oxidant 
chemistry (McKay et al., 2003; Navarro-González et al., 2003; Cockell et al., 2008; Georgiou et al., 2015). In addition, organisms in the soils are exposed to large temperature and relative humidity $(\mathrm{RH})$ fluctuations, often in excess of $40^{\circ} \mathrm{C}$ and $70 \%$, respectively (McKay et al., 2003). Deeper soils are not affected by UV radiation, the oxidant flux is lower, and temperature and RH fluctuations are less extreme, making them less relevant for long-term martian habitability.

Our initial assumption was that metabolic activity and growth of microorganisms over time would be reflected in the composition of their lipid membranes, particularly in the presence of lipid indicators of stress as microorganisms face extreme environmental conditions. For example, many bacteria transform unsaturated membrane fatty acids into CFAs when exposed to oxidants, starvation, and desiccation (Marr and Ingraham, 1962; Guckert et al., 1986; Grogan and Cronan, 1997; Annous et al., 1999; Chen and Gänzle, 2016). CFAs are crucial for enhancing the stability of bacterial membranes under environmental stress, decreasing membrane permeability against toxic compounds (Poger and Mark, 2015), and aiding in bacteria revival after freezedrying (Muñoz-Rojas et al., 2006). The formation of CFAs in Escherichia coli is a postsynthetic modification of the phospholipid bilayer that occurs predominantly as cultures enter the stationary phase of growth (Wang and Cronan, 1994; Hartig et al., 2005), and therefore, they are expected to be present if conditions are stressful but still compatible with metabolic rates conducive to growth and reproduction, rather than just cellular maintenance and survival. Another bacterial lipid marker of stress is the ratio of trans to cis unsaturated fatty acid isomers. The conversion of cis unsaturated fatty acids to trans is an emergency action used by bacteria to modulate membrane fluidity in response to environmental stressors (Guckert et al., 1986; Okuyama et al., 1991; Heipieper et al., 1995, 1996, 2003; Loffeld and Keweloh, 1996).

CFAs were detected at the biological positive control sites Chañaral and Altamira (53-128 pg CFA/g soil), but were not detected in the three hyperarid surface soils (Fig. 5), a result that is consistent with previous reports of the absence of this type of compound in Yungay soils (Connon et al., 2007). In addition, the trans/cis ratio of the fatty acid $n-\mathrm{C}_{16: 1 \Delta 9}$ decreased from the biologic control sites to the hyperarid sites (Fig. 6), contrary to what would be expected from bacterial communities adapting to increasingly dry conditions and oxidative stress, or starving microorganisms (Hartig et al., 2005). One possible explanation for the disappearance of CFAs toward the driest sites is that the signal was too low due to low biomass. However, cell concentrations in Yungay soils $\left(\sim 10^{3}\right.$ cells $\left./ g\right)$ are only 5-10 times lower than cell concentrations at the biological positive control sites (CritsChristoph et al., 2013) and the total SFA content of Yungay surface soils is only 4.6-17.2 times lower at the biological positive control sites (Fig. 3). Thus, a relative abundance of CFAs in cell membranes similar to the biological positive control sites ought to generate a signal well above the limit of detection of our technique $(\leq 1 \mathrm{pg} \mathrm{CFA} / \mathrm{g}$ soil, see the Methods section). There are no known microbial mechanisms to reverse the cyclopropanation of phospholipid fatty acids within the membrane (Zhang and Rock, 2008), and the cyclopropane functionality is stable (Zhang and Rock,
2008). Therefore, once formed, these recalcitrant compounds ought to accumulate over time given the low carbon cycling rates (Ewing et al., 2008) and the excellent preservation conditions for lipid biomarkers (especially fatty acids) over timescales of tens of thousands to millions of years in these hyperarid soils (Wilhelm et al., 2017). We argue instead that the observed trends in stress lipid indicators reflect the long-term metabolic state of organisms in the surface soils, rather than biomass abundance.

In laboratory settings, increases in the ratio of trans/cis unsaturated fatty acids and the synthesis of CFAs are both observable after a week to 1 month of exposure to a stressor (Guckert et al., 1986), and their synthesis rates are particularly dependent on growth phase, with higher rates of CFA production during the transition from exponential to stationary growth (Hartig et al., 2005), and higher rates of trans unsaturated fatty acid production during the transition from a growth phase to a starvation state (Hartig et al., 2005). In situ soil incubation experiments in the Yungay region have shown that abiotic chemistry dominates over biotic chemistry over short timescales (Navarro-González et al., 2003), and longer term laboratory incubations revealed metabolic activity only after 7 days (Crits-Christoph et al., 2013). However, surface soils at the driest sites typically dry up within hours to a few days after an average rain event (Davis et al., 2010). Therefore, the absence or lower relative abundances of lipid stress indicators in the driest surface soils relative to the biological positive control soils suggest that the microorganisms contained in them are not hydrated long enough, or are too starved, to enter a growth phase and modify their membranes.

The low relative abundance of trans fatty acids in the driest sites could also be due to external inputs of biomass, such as atmospheric deposition, outweighing in situ production (i.e., signal dilution). Signal dilution via input of biomass from external sources is supported by immunoprofiles of soil samples, which revealed the presence of peptides indicative of proteins that are either synthesized by plants or have a close homologue synthesized by plants. These include the following: DhnA, a dehydrin protein found in plants under desiccation stress; HR, a homologue of the detected WshR protein used by plants in defense against bacterial pathogens (Wright and Beattie, 2004); and HtpG, a heat shock protein found in E. coli (Spence and Georgopoulos, 1989) that is $42 \%$ identical to the hsp90 protein found in some plants (Krishna and Gloor, 2001). Given the lack of native plants in the three driest locations (although in the Yungay region there were a few trees planted by humans c.a. $10 \mathrm{~km}$ away from our sampling site), it is likely that one or more of these peptides were not synthesized in the soils, but were instead generated elsewhere and deposited via aeolian processes.

We also detected peptides indicative of cyanobacterial proteins (i.e., IsiA, SodA, SodF, and HtpG proteins) (Shirkey et al., 2000; Hossain and Nakamoto, 2002, 2003; Chen and Bibby, 2005; Wilson et al., 2007), which is at odds with the absence of detectable cyanobacterial DNA in Yungay (Lester et al., 2007; Crits-Christoph et al., 2013) and Maria Elena (Azua-Bustos et al., 2015) soils, and also points to external sources or relic biomass from a past wetter period. A few of the peptides that were detected in the hyperarid soils appeared to lack structural integrity based on the lack 
of signal from the several epitopes targeted in the same protein (e.g., in contrast with the biological control sites where multiple portions of the same proteins were always detected suggesting that the proteins/peptides were intact). These proteins include $\mathrm{PhaC}$, nitrogenase molybdenum-iron protein alpha chain (NifD), and nitrogenase iron (NifH). A lack of protein integrity in the driest surface soils indicates that the rate of destruction is greater than the rate of production and/or deposition of intact proteins.

Finally, the D/L ratio of aspartic acid in the driest soils $(\mathrm{D} / \mathrm{L}=0.1-0.13)$ compared to the Chañaral site $(\mathrm{D} / \mathrm{L}=0.02)$ (Fig. 7) was also indicative of diminishing rates of biomass turnover. Aspartic acid has one of the highest rates of racemization (Poinar et al., 1996), which makes it a useful "clock" for dating biomass that is a few thousands to tens of thousands of years old. Using a previously reported expression for calculating the "dry" sample age based on $\mathrm{D} / \mathrm{L}$ ratios of aspartic acid in the Atacama (Skelley et al., 2007), our measured ratio returned a "dry" age of $\sim 14,000$ years in Yungay, within the range of previous estimates $\left(10^{3}-10^{5}\right.$ years) in the same area (Skelley et al., 2007). Since the $\mathrm{D} / \mathrm{L}$ ratio likely reflects a mixing of two components (new biomass and relic biomass), the derived age must be taken as an approximation rather than a precise value. However, the measured $\mathrm{D} / \mathrm{L}$ ratio is consistent with our interpretation of limited metabolic recycling of organic matter over long periods of time.

Taken together, the absence of CFAs in cells at the driest sites; the association of some of the detected stress peptides/ proteins with plants or cyanobacteria known to be absent in the hyperarid soils; the lack of structural integrity of some of the proteins; and the higher D/L ratio of aspartic acid compared to the biological control are all consistent with signal suppression (lack of growth) and/or signal dilution from external sources, and confirm previous studies that suggested that the sparse microbial population in the driest surface soils in the Atacama is primarily derived from atmospheric inputs (Connon et al., 2007; Lester et al., 2007), and atmospheric deposition dominates the input of organics into the soils (Ewing et al., 2008).

In the driest region of one of the driest deserts on Earth, water availability is too low to allow for significant growth in the surface soil microbial population. This presents a unique set of trends in biomarker content of soils, distinguishing it from others, only slightly wetter surface soils within the desert (Fig. 9). These features include (1) a lack of colonization by plants and lichens, (2) a lack of lipids that indicate membrane modulation in response to deleterious environmental conditions (such as CFAs and trans/cis ratios of unsaturated fatty acids) (Figs. 5 and 6), (3) significant racemization of amino acids contained in surface soils (Fig. 7), (4) a relatively low abundance and diversity of biomass/Total Organic Carbon (TOC) (Figs. 3, 4, and 8) (Ewing et al., 2008; Crits-Christoph et al., 2013), and (5) a $<1 \%$ colonization of stones by hypolithic organisms (WarrenRhodes et al., 2006). These biomarker characteristics would be worth exploring in other hyperarid terrestrial regions that experience similarly low levels of water activities, such as the University Valley portion of the McMurdo Dry Valleys in Antarctica (Goordial et al., 2016), where water availability to organisms is limited by cold temperatures.

\subsection{Implications for Mars habitability, preservation and detectability of molecular biomarkers}

Our data suggest that microbial growth is negligible or completely absent in the driest Atacama soils, and that most of the biomass in these soils is likely derived from degraded remains of a soil community left over from a previous wetter epoch and/or the accumulation of atmospheric deposition. Given the longevity and duration of hyperarid conditions in the Atacama Desert (Clarke, 2006), these

\section{Differences in Biomarker Content of Surface Soils Under Increasingly Dry Conditions}

\begin{tabular}{|c|c|c|}
\hline BIOLOGICALLY INACTIVE & & BIOLOGICALLY ACTIVE \\
\hline $\begin{array}{l}\text { - No visible plants or lichens } \\
\text { - No lipid indicators of bacterial } \\
\text { membrane modification } \\
\text { - Low biomass abundance } \\
\text { - Low biomass diversity } \\
\text { - Significant racemization of } \\
\text { amino acids } \\
\text { - <1\% hypolithic colonization }\end{array}$ & $\begin{array}{l}\text { TRANSITION } \\
\text { ZONE }\end{array}$ & $\begin{array}{l}\text { - Sparse plants or lichens } \\
\text { - Lipid indicators of bacterial } \\
\text { membrane modification } \\
\text { - Higher biomass abundance } \\
\text { - Higher biomass diversity } \\
\text { - Slight to no racemization of } \\
\text { amino acids } \\
\text { - >10\% hypolithic colonization }\end{array}$ \\
\hline $\begin{array}{l}\text { extreme hyperarid } \\
\mathrm{Al}<0.003\end{array}$ & & $\begin{array}{c}\text { hyperarid } \\
0.003<\mathrm{Al}<0.05\end{array}$ \\
\hline
\end{tabular}

FIG. 9. Conceptual figure showing differences in biomarker content of surface soils under increasingly dry conditions in hyperarid environments. Key differences are observed in soil biomarker content along the Atacama's aridity transect, including lipids, amino acid racemization, and peptides (this article), and hypolithic colonization (Warren-Rhodes et al., 2006) that suggests that there is minimal or no in situ microbial growth in the driest surface soils of the Atacama. 
results add to a mounting body of evidence that the surface soils in the driest parts of the desert define the dry limit of adaptation and growth on Earth (Navarro-González et al., 2003; Ewing et al., 2006; Warren-Rhodes et al., 2006). We cannot rule out that basal levels of metabolic activity occur after sporadic rain events, sufficient for cell maintenance and survival, but in the absence of external sources of biomass, such basal levels of metabolic activity would be insufficient for the long-term persistence of the soil population.

The martian environment is 100-1000 times drier than the driest parts of the Atacama (Davila and Schulze-Makuch, 2016). In addition, Mars is significantly more hostile to life due to colder temperatures (with larger temperature fluctuations), greater fluxes of UV radiation, and soil oxidants. Therefore, surface soils in the driest parts of the Atacama Desert might be considered a best-case biologic scenario for Mars. If the small, decadal rain events in the extreme hyperarid region of the Atacama are not enough to sustain soil organisms over long timescales, then stochastic and sparse liquid water activity in martian soils (e.g., Martín-Torres et al., 2015) is also likely insufficient to sustain cell growth. Hence, any biological signal in martian soils would likely have originated from nonsoil sources (i.e., McKay et al., 1992; Davila et al., 2010; Davila and Schulze-Makuch, 2016), or would likely represent relic biomass from a past, wetter period.

If sufficiently protected from radiation and other degradative processes, this biological signal might still be preserved over long periods of time due to the extreme dryness (Wilhelm et al., 2017) in the structure and composition of organic molecules such as amino acids (i.e., homochirality), lipids (i.e., even-over-odd chain length preferences), or complex biological polymers (Summons et al., 2008). Fatty acid concentrations in martian soils, equivalent to those in Yungay ( $20 \mathrm{fmol} / \mathrm{g}-120 \mathrm{pmol} / \mathrm{g}$ ), would be theoretically detectable by the Sample Analysis at Mars (SAM) GC-MS aboard the Mars Science Laboratory (limit of detection for benzene and hexane in the picomole range) (Mahaffy et al., 2012).

\section{Conclusions}

Our novel use of an array of long-term biochemical markers of metabolic activity such as lipids, amino acids, and peptides in hyperarid Atacama surface soils reveals that metabolic activity in the driest soils is, at best, insufficient to sustain cell growth, only maintenance and survival. Lipid and peptide data point to biomolecules not currently being synthesized in situ, and perhaps transported from more active regions in the Atacama and deposited in extreme hyperarid soils. Amino acid racemization data suggest that this biological material is then left to slowly degrade over timescales of tens of thousands of years in surface soils. Despite the nonhabitability of the driest Atacama surface soils under the current climatic conditions, clearly biogenic biomarkers and biomolecular trends are well preserved. Our results have implications for long-term habitability models of Mars.

\section{Acknowledgments}

The authors acknowledge support from the ARADS project under NASA's PSTAR program. M.N.P. acknowledges funding from NASA Exobiology Program (Grant NNX15AM17G). A.F.D. acknowledges support from the
NASA Astrobiology Institute (NAI Grant NNX15BB01A to the SETI Institute) to contribute to writing of the article. V.P.G., M.G.V., and Y.B. were supported by the Spanish Ministry of Economy and Competitiveness (MINECO), Grant No. ESP2015-69540-R. The authors thank Tori Hoehler for helpful discussions.

\section{Author Disclosure Statement}

No competing financial interests exist.

\section{References}

Annous, B.A., Kozempel, M.F., and Kurantz, M.J. (1999) Changes in membrane fatty acid composition of Pediococcus sp. strain NRRL B-2354 in response to growth conditions and its effect on thermal resistance. Appl Environ Microbiol 65: 2857-2862.

Azua-Bustos, A., Caro-Lara, L., and Vicuña, R. (2015) Discovery and microbial content of the driest site of the hyperarid Atacama Desert, Chile. Environ Microbiol Rep 7:388-394.

Bada, J.L., Wang, X.S., and Hamilton, H. (1999) Preservation of key biomolecules in the fossil record: current knowledge and future challenges. Philos Trans R Soc Lond B Biol Sci 354:77-87.

Blanco, Y., Moreno-Paz, M., and Parro, V. (2017) Experimental protocol for detecting cyanobacteria in liquid and solid samples with an antibody microarray chip. $J$ Vis $\operatorname{Exp}$ 17:120.

Bligh, E.G. and Dyer, W.J. (1959) A rapid method of total lipid extraction and purification. Can J Biochem Physiol 37:911-917.

Carr, M.H. and Head, J.W., III (2010) Geologic history of Mars. Earth Planet Sci Lett 294:185-203.

Chen, M. and Bibby, T.S. (2005) Photosynthetic apparatus of antenna-reaction centres supercomplexes in oxyphotobacteria: insight through significance of Pcb/IsiA proteins. Photosynth Res 86:165-173.

Chen, Y.Y. and Gänzle, M.G. (2016) Influence of cyclopropane fatty acids on heat, high pressure, acid and oxidative resistance in Escherichia coli. Int J Food Microbiol 222:16-22.

Clarke, J.D. (2006) Antiquity of aridity in the Chilean Atacama Desert. Geomorphology 73:101-114.

Cockell, C.S., Bush, T., Bryce, C., Direito, S., Fox-Powell, M., Harrison, J.P., Lammer H., Landenmark H., Martin-Torres J., Nicholson N., and Noack, L. (2016) Habitability: a review. Astrobiology 16:89-117.

Cockell, C.S., McKay, C.P., Warren-Rhodes, K., and Horneck, G. (2008) Ultraviolet radiation-induced limitation to epilithic microbial growth in arid deserts-dosimetric experiments in the hyperarid core of the Atacama Desert. J Photochem Photobiol B 90:79-87.

Connon, S.A., Lester, E.D., Shafaat, H.S., Obenhuber, D.C., and Ponce, A. (2007) Bacterial diversity in hyperarid Atacama Desert soils. J Geophys Res Biogeosci 112:G4.

Crits-Christoph, A., Robinson, C.K., Barnum, T., Fricke, W.F., Davila, A.F., Jedynak, B., McKay, C.P., and DiRuggiero, J. (2013) Colonization patterns of soil microbial communities in the Atacama Desert. Microbiome 1:28.

Davila, A.F., Duport, L.G., Melchiorri, R., Jänchen, J., Valea, S., de los Rios, A., Fairén A.G., Möhlmann D., McKay C.P., Ascaso C., and Wierzchos, J. (2010) Hygroscopic salts and the potential for life on Mars. Astrobiology 10:617-628.

Davila, A.F. and Schulze-Makuch, D. (2016) The last possible outposts for life on Mars. Astrobiology 16:159-168.

Davis, W.L., de Pater, I., and McKay, C.P. (2010) Rain infiltration and crust formation in the extreme arid zone of the Atacama Desert, Chile. Planet Space Sci 58:616-622. 
Ewing, S.A., Macalady, J.L., Warren-Rhodes, K., McKay, C.P., and Amundson, R. (2008) Changes in the soil C cycle at the arid-hyperarid transition in the Atacama Desert. J Geophys Res Biogeosci 113:G2.

Ewing, S.A., Sutter, B., Owen, J., Nishiizumi, K., Sharp, W., Cliff, S.S., Perry, K., Dietrich, W., McKay, C.P., and Amundson, R. (2006) A threshold in soil formation at Earth's arid-hyperarid transition. Geochim Cosmochim Acta 70: 5293-5322.

Georgiou, C.D., Sun, H.J., McKay, C.P., Grintzalis, K., Papapostolou, I., Zisimopoulos, D., Panagiotidis K., Zhang G., Koutsopoulou E,. Christidis G.E., and Margiolaki, I. (2015) Evidence for photochemical production of reactive oxygen species in desert soils. Nat Commun 6:7100.

Goordial, J., Davila, A., Lacelle, D., Pollard, W., Marinova, M.M., Greer, C.W., DiRuggiero, J., McKay, C.P., and Whyte, L.G. (2016) Nearing the cold-arid limits of microbial life in permafrost of an upper dry valley, Antarctica. ISME $J 10$ : 1613-1624.

Grogan, D.W. and Cronan, J.E. (1997) Cyclopropane ring formation in membrane lipids of bacteria. Microbiol Mol Biol Rev 61:429-441.

Guckert, J.B., Hood, M.A., and White, D.C. (1986) Phospholipid ester-linked fatty acid profile changes during nutrient deprivation of Vibrio cholerae: increases in the trans/cis ratio and proportions of cyclopropyl fatty acids. Appl Environ Microbiol 52:794-801.

Hartig, C., Loffhagen, N., and Harms, H. (2005) Formation of trans fatty acids is not involved in growth-linked membrane adaptation of Pseudomonas putida. Appl Environ Microbiol 71:1915-1922.

Heipieper, H.J., Loffeld, B., Keweloh, H., and de Bont, J.A. (1995) The cis/trans isomerisation of unsaturated fatty acids in Pseudomonas putida S12: an indicator for environmental stress due to organic compounds. Chemosphere 30:10411051.

Heipieper, H.J., Meinhardt, F., and Segura, A. (2003) The cistrans isomerase of unsaturated fatty acids in Pseudomonas and Vibrio: biochemistry, molecular biology and physiological function of a unique stress adaptive mechanism. FEMS Microbiol Lett 229:1-7.

Heipieper, H.J., Meulenbeld, G., van Oirschot, Q.U., and De Bont, J. (1996) Effect of environmental factors on the trans/ cis ratio of unsaturated fatty acids in Pseudomonas putida S12. Appl Environ Microbiol 62:2773-2777.

Hossain, M.M. and Nakamoto, H. (2002) HtpG plays a role in cold acclimation in cyanobacteria. Curr Microbiol 44:291296.

Hossain, M.M. and Nakamoto, H. (2003) Role for the cyanobacterial HtpG in protection from oxidative stress. Curr $\mathrm{Mi}$ crobiol 46:70-76.

Jahnke, L.L., Stan-Lotter, H., Kato, K., and Hochstein, L.I. (1992) Presence of methyl sterol and bacteriohopanepolyol in an outer-membrane preparation from Methylococcus capsulatus (Bath). J Gen Microbiol 138:1759-1766.

Kates, M. (1986) Techniques of Lipidology: Isolation, Analysis, and Identification of Lipids, $2^{\text {nd }}$ revised ed., Elsevier, Amsterdam, pp 123-127.

Krishna, P. and Gloor, G. (2001) The Hsp90 family of proteins in Arabidopsis thaliana. Cell Stress Chaperones 6: 238-246.

Lester, E.D., Satomi, M., and Ponce, A. (2007) Microflora of extreme arid Atacama Desert soils. Soil Biol Biochem 39: 704-708.
Loffeld, B. and Keweloh, H. (1996) Cis/trans isomerization of unsaturated fatty acids as possible control mechanism of membrane fluidity in Pseudomonas putida P8. Lipids 31:811-815.

Mahaffy, P.R., Webster, C.R., Cabane, M., Conrad, P.G., Coll, P., Atreya, S.K., Arvey R., Barciniak M., Benna M., Bleacher L., and Brinckerhoff, W.B. (2012) The sample analysis at Mars investigation and instrument suite. Space Sci Rev 170: 401-478.

Marr, A.G. and Ingraham, J.L. (1962) Effect of temperature on the composition of fatty acids in Escherichia coli. J Bacteriol 84:1260-1267.

Martín-Torres, F.J., Zorzano, M.P., Valentín-Serrano, P., Harri, A.M., Genzer, M., Kemppinen, O., Rivera-Valentin, E.G., Jun, I., Wray, J., Madsen, M.B., and Goetz, W. (2015) Transient liquid water and water activity at Gale crater on Mars. Nat Geosci 8:357-361.

McKay, C.P., Friedmann, E.I., Gómez-Silva, B., CáceresVillanueva, L., Andersen, D.T., and Landheim, R. (2003) Temperature and moisture conditions for life in the extreme arid region of the Atacama Desert: four years of observations including the El Nino of 1997-1998. Astrobiology 3:393406.

McKay, C.P., Imre Friedman, E., Wharton, R.A., and Davies, W.L. (1992) History of water on Mars: a biological perspective. Adv Space Res 12:231-238.

Meadow, J.F., Altrichter, A.E., Bateman, A.C., Stenson, J., Brown, G.Z., Green, J.L., and Bohannan, B.J. (2015) Humans differ in their personal microbial cloud. PeerJ 3:e1258.

Morita, R.Y. (1998) Bacteria in oligotrophic environments. Starvation-survival lifestyle. Limnol Oceanogr 43:10211022.

Muñoz-Rojas, J., Bernal, P., Duque, E., Godoy, P., Segura, A., and Ramos, J.L. (2006) Involvement of cyclopropane fatty acids in the response of Pseudomonas putida KT2440 to freeze-drying. Appl Environ Microbiol 72:472-477.

Navarro-González, R., Rainey, F.A., Molina, P., Bagaley, D.R., Hollen, B.J., de la Rosa, J., Small, A.M., Quinn, R.C., Grunthaner, F.J., Cáceres, L., Gomez-Silva, B., and McKay, C.P. (2003) Mars-like soils in the Atacama Desert, Chile, and the dry limit of microbial life. Science 302:1018-1021.

Ojha, L., Wilhelm, M.B., Murchie, S.L., McEwen, A.S., Wray, J.J., Hanley, J., Massé, M. and Chojnacki, M. (2015) Spectral evidence for hydrated salts in recurring slope lineae on Mars. Nat Geosci 8:829.

Okuyama, H., Okajima, N., Sasaki, S., Higashi, S., and Murata, N. (1991) The cis/trans isomerization of the double bond of a fatty acid as a strategy for adaptation to changes in ambient temperature in the psychrophilic bacterium, Vibrio sp. strain ABE-1. Biochim Biophys Acta 1084:13-20.

Parro, V., Blanco, Y., Puente-Sánchez, F., Rivas, L.A., MorenoPaz, M., Echeverria, A., Chong-Díaz, G., Demergasso, C., and Cabrol, N.A. (2016) Biomarkers and metabolic patterns in the sediments of evolving glacial lakes as a proxy for planetary lake exploration. Astrobiology 18:586-606. DOI: 10.1089/ast.2015.1342.

Parro, V., de Diego-Castilla, G., Moreno-Paz, M., Blanco, Y., Cruz-Gil, P., Rodríguez-Manfredi, J.A., Fernández-Remolar, D., Gómez, F., Gómez, M.J., Rivas, L.A., Demergasso, C., Echeverría, A., Urtuvia, V.N., Ruiz-Bermejo, M., GarcíaVilladangos, M., Postigo, M., Sánchez-Román, M., ChongDíaz, G., and Gómez-Elvira, J. (2011) A microbial oasis in the hypersaline Atacama subsurface discovered by a Life Detector Chip: implications for the search for life on Mars. Astrobiology 11:969-996. 
Poger, D. and Mark, A.E. (2015) A ring to rule them all: the effect of cyclopropane fatty acids on the fluidity of lipid bilayers. J Phys Chem B 119:5487-5495.

Poinar, H.N., Hoss, M., Bada, J.L., and Paabo, S. (1996) Amino acid racemization and the preservation of ancient DNA. Science 272:864.

Price, P.B. and Sowers, T. (2004) Temperature dependence of metabolic rates for microbial growth, maintenance and survival. Proc Natl Acad Sci U S A 101:4631-4636.

Rivas, L.A., García-Villadangos, M., Moreno-Paz, M., CruzGil, P., Gómez-Elvira, J., and Parro, V. (2008) A 200antibody microarray biochip for environmental monitoring: searching for universal microbial biomarkers through immunoprofiling. Anal Chem 80:7970-7979.

Shirkey, B., Kovarcik, D.P., Wright, D.J., Wilmoth, G., Prickett, T.F., Helm, R.F., Gregory, E.M., and Potts, M. (2000) Active Fe-containing superoxide dismutase and abundant sodF mRNA in Nostoc commune (cyanobacteria) after years of desiccation. J Bacteriol 182:189-197.

Skelley, A.M., Aubrey, A.D., Willis, P.A., Amashukeli, X., Ehrenfreund, P., Bada, J.L., Grunthaner, F.J., and Mathies, R.A. (2007) Organic amine biomarker detection in the Yungay region of the Atacama Desert with the Urey instrument. $J$ Geophys Res Biogeosci 112:G4.

Spence, J. and Georgopoulos, C. (1989) Purification and properties of the Escherichia coli heat shock protein, HtpG. J Biol Chem 264:4398-4403.

Stevenson, F.J. (1982) Organic forms of soil nitrogen. In $\mathrm{Ni}$ trogen in Agricultural Soils (Nitrogeninagrics), edited by Frank J. Stevenson, American society of Agronomy Inc./Crop Science Society of America Inc./Soil Science Society of America Inc., Madison, Wisconsin USA, pp 67-122.

Summons, R.E., Albrecht, P., McDonald, G., and Moldowan, J.M. (2008) Molecular biosignatures. Strategies of Life Detection, edited by Oliver Botta, Jeffrey L. Bada, Javier Gomez-Elvira, Emman velle Javoux, Franck Selsis, Roger Summons, Springer, Boston MA, pp 133-159.

Wang, A.-Y. and Cronan, J.E. (1994) The growth phasedependent synthesis of cyclopropane fatty acids in Escherichia coli is the result of an RpoS(KatF)-dependent promoter plus enzyme instability. Mol Microbiol 11:10091017.

Warren-Rhodes, K.A., Rhodes, K.L., Pointing, S.B., Ewing, S.A., Lacap, D.C., Gómez-Silva, B., Amundson, R., Friedmann, E.I., and McKay, C.P. (2006) Hypolithic cyanobacteria, dry limit of photosynthesis, and microbial ecology in the hyperarid Atacama Desert. Microb Ecol 52:389-398.
Wilhelm, M.B., Davila, A.F., Eigenbrode, J.L., Parenteau, M.N., Jahnke, L.L., Liu, X.L., Summons, R.E., Wray, J.J., Stamos, B.N., O'Reilly, S.S., and Williams, A. (2017) Xeropreservation of functionalized lipid biomarkers in hyperarid soils in the Atacama Desert. Org Geochem 103:97-104.

Wilson, A., Boulay, C., Wilde, A., Kerfeld, C.A., and Kirilovsky, D. (2007) Light-induced energy dissipation in ironstarved cyanobacteria: roles of OCP and IsiA proteins. Plant Cell 19:656-672.

Wright, C.A. and Beattie, G.A. (2004) Pseudomonas syringae pv. tomato cells encounter inhibitory levels of water stress during the hypersensitive response of Arabidopsis thaliana. Proc Natl Acad Sci U S A 101:3269-3274.

Yamamoto, K., Shibahara, A., Nakayama, T., and Kajimoto, G. (1991) Determination of double-bond positions in methyleneinterrupted dienoic fatty acids by GC-MS as their dimethyl disulfide adducts. Chem Phys Lipids 60:39-50.

Zhang, Y.M. and Rock, C.O. (2008) Membrane lipid homeostasis in bacteria. Nat Rev Microbiol 6:222-233.

\section{Address correspondence to: Mary Beth Wilhelm NASA Ames Research Center M.S. 245-3 Moffett Field, CA 94035}

E-mail: marybeth.wilhelm@nasa.gov

Submitted 14 June 2017

Accepted 3 March 2018 Associate Editor: Christopher McKay

$\begin{aligned} & \text { Abbreviations Used } \\ \mathrm{AI} & =\text { aridity index } \\ \mathrm{ATP} & =\text { adenosine triphosphate } \\ \mathrm{CFA} & =\text { cyclopropane fatty acid } \\ \mathrm{CG}-\mathrm{MS} & =\text { gas chromatography/mass spectrometry } \\ \mathrm{DCM} & =\text { methylene chloride } \\ \mathrm{DMDS} & =\text { dimethyl disulfide } \\ \mathrm{FAME} & =\text { fatty acid methyl ester } \\ \mathrm{LDChip} & =\text { life detector chip } \\ \mathrm{RH} & =\text { relative humidity } \\ \mathrm{SFAs} & =\text { saturated fatty acids } \\ \mathrm{TLE} & =\text { total lipid extract } \\ \mathrm{UV} & =\text { ultraviolet } \\ \mathrm{W} \mathrm{shR} & =\text { water stress hypersensitive response }\end{aligned}$

